\title{
PERAN KEPUASAN KERJA UNTUK MENGATASI GAP ANTARA KOMITMEN ORGANISASI TERHADAP KINERJA APARATUR SIPIL NEGARA PADA SEKRETARIAT DAERAH KABUPATEN JAYAPURA
}

\author{
RAHMI \\ Dosen Prodi Manajemen, STIE Port Numbay Jayapura
}

\begin{abstract}
The Role of Job Satisfaction To Overcome The Gap Between Organizational Commitment And The Performance Of The State Civil Apparatus At The Regional Secretariat Of Jayapura Regency. Improving the quality of human resources is a definite need in line with the implementation of regional autonomy. Improving the quality of Civil Servants aims to change their behavior to become more capable in carrying out activities in all fields, because basically human behavior can affect every action in achieving the goals to be achieved. This study aims to determine the effect of the organizational commitment variable on the performance of civil servants through job satisfaction as an intervening variable. This type of research is associative research using a quantitative approach. The population in this study were all civil servants in the Regional Secretariat of Jayapura Regency as many as 166 people. While the sampling technique used a saturated sample where all employees were sampled. Data collection techniques were carried out by distributing questionnaires. The data analysis technique used is Structural Equation Modeling (SEM) with the help of the AMOS version 24 program.The results in this study indicate that: (1) organizational commitment has no effect on employee performance at the Regional Secretariat of Jayapura Regency; (2) organizational commitment has a positive and significant effect on job satisfaction at the Regional Secretariat of Jayapura Regency; (3) Job satisfaction has a positive and significant effect on employee performance at the Regional Secretariat of Jayapura Regency; (4) $\mathrm{Job}$ satisfaction can mediate the effect of organizational commitment on employee performance at the Regional Secretariat of Jayapura Regency.
\end{abstract}

\section{Keywords: Organizational Commitment, Work Goals, Performance of State Civil Apparatus}

Abstrak: Peran Kepuasan Kerja Untuk Mengatasi Gap Antara Komitmen Organisasi Terhadap Kinerja Aparatur Sipil Negara Pada Sekretariat Daerah Kabupaten Jayapura.Peningkatan kualitas sumber daya manusia merupakan kebutuhan pasti seiring diterapkannya otonomi daerah. Peningkatan kualitas Pegawai Negeri Sipil bertujuan untuk mengubah perilaku mereka menjadi lebih mampu melaksanakan aktivitas di segala bidang, karena pada dasarnya perilaku manusia dapat mempengaruhi setiap tindakan dalam mencapai tujuan yang ingin dicapai. Penelitian ini bertujuan untuk mengetahui pengaruh variabel komitmen organisasional terhadap kinerja aparatur sipil Negara melalui kepuasan kerja sebagai variabel intervening. Jenis penelitian ini adalah penelitian asosiatif dengan menggunakan pendekatan kuantitatif. Populasi dalam penelitian ini adalah seluruh aparatur sipil negarapada Sekretariat Daerah Kabupaten Jayapura sebanayak 166 orang. Sedangkanteknik pengambilan sampel menggunakan sampel jenuhdimana seluruh pegawai dijadikan sebagai sampel. Teknik pengumpulan data dilakukan dengan menyebarkan kuesioner. Teknik analisis data yang digunakan adalahStructural Equation Modeling(SEM) dengan bantuan program AMOS versi 24.Hasil dalam penelitian ini menunjukkan bahwa: (1) Komitmen organisasi tidak berpengaruh terhadap kinerja pegawai pada Sekretariat Daerah Kabupaten Jayapura; (2) Komitmen organisasi berpengaruh positif dan signifikan terhadap kepuasan kerja pada Sekretariat Daerah Kabupaten Jayapura; (3) Kepuasan kerja berpengaruh positif dan signifikan terhadap kinerja pegawai pada Sekretariat Daerah Kabupaten Jayapura; (4) Kepuasan kerja dapat memediasi pengaruh komitmen organisasi terhadap kinerja pegawai pada Sekretariat Daerah Kabupaten Jayapura

Kata Kunci : Komitmen Organisasional, Kepuasan Kerja, Kinerja Aparatur Sipil Negara

\section{LATAR BELAKANG}

Peningkatan kualitas sumber daya manusia merupakan kebutuhan pasti seiring diterapkannya otonomi daerah. Peningkatan kualitas Pegawai Negeri Sipil bertujuan untuk mengubah perilaku mereka menjadi lebih mampu melaksanakan aktivitas di segala bidang, karena pada dasarnya perilaku manusia dapat mempengaruhi setiap tindakan dalam mencapai tujuan yang ingin dicapai.

Sekretariat Daerah Kabupaten Jayapura sebagai pusat pemerintahan di Kabupaten Jayapura mempunyai peranan yang cukup strategis dalam memberikan pelayanan baik kepada masyarakat maupun badan atau dinas atau kantor yang berada di Kabupaten Jayapura. Dengan demikian diharapkan Sekretariat Daerah mampu melaksanakan fungsi-fungsi pemerintahan dengan sebaik-baiknya, terutama fungsi pelayanan. Dengan demikian, efektivitas Manajemen Sumber Daya Manusia di lingkungan Sekretariat Daerah Kabupaten Jayapura perlu ditingkatkan, yaitu dengan menerapkan kinerja pegawai seoptimal mungkin.

Mangkunegara dalam Novita, Sunuharjo, \& Ruhana, (2016) mengungkapkan, "Istilah kinerja berasal dari kata Job Performance atau Actual Performance. Pengertian kinerja 
adalah hasil kerja secara kualitas dan kuantitas yang dicapai oleh seorang pegawai dalam melaksanakan tugasnya sesuai dengan tanggung jawab yang diberikannya".Permasalahan yang mempengaruhi kinerja pegawai pada Kantor Sekretariat Daerah Kabupaten Jayapura menurun adalah pegawai yang kurang memiliki komitmen organisasional. Ini dapat dilihat meningkatnya kelambanan kerja, masih adanya pegawai yang memanfaatkan waktu kerja untuk melakukan hal-hal diluar pekerjaannya, tingginya absensi pegawai dan banyak pegawai yang meninggalkan kantor pada jam kerja.

Komitmen kerja (work commitment) dankepuasan kerja (job satisfaction) adalah topik yangpopulardalam penelitian mengenai pekerjaan berhubungan dengan sikap (attitude). Komitmen kerja dan kepuasan kerja adalah variabel yang berhubungan dan mempengaruhi kinerja kerja (job performance) (Mathieu \& Zajac, 1990). Tingginya komitmen organisasi akan berpengaruh terhadap tingginya kinerja pegawai. Penelitian yang dilakukan oleh Akbar, Hamid, \& Djudi (2016); Suryahadi (2015); Susanti \& Palupiningdyah (2016) menunjukan bahwa komitmen organisasi berpengaruh positif dan signifikan terhadap kinerja. Artinya ketika komitmen organisasi meningkat maka kinerja juga akan mengalami peningkatan. Namun, penelitian yang dilakukan oleh Mekta \& Siswanto (2017); Novita et al.(2016)menunjukkan hasil yang berbeda. Hasil penelitiannya menunjukkan hasil yang negatif terhadap kinerja. Artinya ketika komitmen organisasi meningkat, maka kinerja mengalami penurunan.

Selain itu kinerja pegawai juga dipengaruhi tingginya kepuasan kerja. Hasil penelitian dilakukan oleh (Fadhil \& Mayowan, 2018; Novita et al., 2016; Suryahadi, 2015; Susanti \& Palupiningdyah(2016)menunjukan bahwa kepuasan kerja berpengaruh positif dan signifikan terhadap kinerja. Artinya ketika kepuasan kerja meningkat maka kinerja juga akan mengalami peningkatan. Sedangkan hasil penelitian yang dilakukan Kristine(2017) menunjukan hasil yang berbeda yaitu kepuasan kerja berpengaruh negatif terhadap kinerja. Artinya ketika kepuasan kerja meningkat, akan mengakibatkan penurunan kinerja.

\section{Rumusan Masalah}

1. Apakah Komitmen organisasi berpengaruh terhadap Kinerja Aparatur Sipil Negara di Sekretariat Daerah Kabupaten Jayapura?

2. Apakah Komitmen organisasi berpengaruh terhadap kepuasan kerja Aparatur Sipil Negara di Sekretariat Daerah Kabupaten Jayapura?

3. Apakah Kepuasan kerja berpengaruh terhadap Kinerja Aparatur Sipil Negara di Sekretariat Daerah Kabupaten Jayapura?

4. Apakah Komitmen organisasi berpengaruh terhadap Kinerja Aparatur Sipil Negara melalui kepuasan kerja di Sekretariat Daerah Kabupaten Jayapura?

\section{KAJIAN PUSTAKA \\ Komitmen Organisasional}

Komitmen organisasional merupakan suatu sikap yang merefleksikan perasaan suka atau tidak suka dari karyawan terhadap organisasi. Komitmen karyawan pada organisasi sebagai ikatan kejiwaan individu terhadap organisasi yang mencangkup keterlibatan kerja, kesetiaan, dan perasaan percaya terhadap nilai-nilai organisasi. Bentuk komitmen yang muncul bukan hanya bersifat loyalitas yang pasif tetapi harus memberikan segala usaha demi keberhasilan organisasi yang bersangkutan (Robbins; O'Reilly; Steers dan Porter; dalam .Sopiah, 2008).

Menurut Newstroom; Hunt dan Morgan; Steers dan Black (dalam Sopiah, 2008) komitmen organisasional ditandai oleh tiga hal, yaitu rasa percaya yang kuat dan penerimaan seorang terhadap tujuan dan nilai-nilai organisasi, keinginan seseorang untuk melakukan usaha secara sungguh-sungguh demi organisasi, dan hasrat yang kuat untuk mempertahankan keanggotaan dalam suatu organisasi.

Mayer et al. (dalam Sopiah, 2008) mengemukanan bahwa ada tiga komponen komitmen organisasional, yaitu: 1). Affective commitment, terjadi apabila karyawan ingin menjadi bagian dari organisasi karena adanya ikatan emosional. 2). Continuance commitment muncul, apabila karyawan tetap bertahan pada suatu organisasi karena membutuhkan gaji, dan keuntungan-keuntungan lain, atau karena karyawan tersebut tidak menemukan pekerjaan lain. Dan 3). Normative commitment, timbul dari nilai dalam diri karyawan. Karyawan bertahan menjadi anggota organisasi karena adanya kesadaran bahwa komitmen terhadap organisasi merupakan hal yang seharusnya dilakukan.

Menurut Robbins \& Judge(2008:725) komitmen pegawaimerupakan usaha mendefinisikan dan melibatkan diri dalam organisasi dan tidak ada keinginan meninggalkannya. Komitmen terhadap organisasi menunjukkan usaha pegawai dan kemauan mengerahkan segala upaya untuk kepentingan organisasi serta berminat tetap menjadi bagian dari organisasi.

Komitmen organisasi dapat menggambarkan keinginan pegawai untuk ikut berperan serta dalam mencapai tujuan organisasi dan loyalitas pegawai terhadap organisasi.Lincoln dan Bashaw dalam Sopiah(2008) komitmen organisasi memiliki tiga indikator yaitu :

a. Kemauan pegawai, dimana adanya keinginan pegawai untuk mengusahakan agar tercapainya kepentingan organisasi.

b. Kesetiaan pegawai, yang mana pegawai berkeinginan untuk mempertahankan keanggotaannya untuk terus menjadi salah satu bagian dari organisasi.

c. Kebanggaan pegawai, ditandai dengan pegawai merasa bangga telah menjadi bagian dari organisasi yang diikutinya dan merasa bahwa organisasi tersebut telah menjadi bagian dalam hidupnya.

\section{Kepuasan Kerja}

Menurut pendapat Robbins \& Judge (2008) istilah kepuasan kerja merujuk kepada sikap umumseorang individu terhadap pekerjaan yang dilakukannya. Seseorang dengan tingkat kepuasan kerja tinggi menunjukan sikap yang positif terhadap kerja itu, sedangkan seseorang yang tidak puas denganpekerjaannya menunjukan sikap yang negatif terhadap pekerjaan itu. 
Hasibuan(2003) mendefinisikan kepuasankerja sebagai sikap emosional yang menyenangkan dan mencintai pekerjaannya. Sikap ini dicerminkan oleh moral kerja, kedisiplinan, dan prestasi kerja. Menurutnya, kepuasan kerja juga dapat dinikmati dalam pekerjaan, luar pekerjaan, serta kombinasi dalam dan luar pekerjaan. Kepuasan kerja yang dirasakan setiap orang tidaklah sama, setiap individu akan memiliki tingkat kepuasan yang berbeda-beda sesuai dengan sistem nilai yang berlaku pada dirinya

Smith dalam Robbins \& Judge(2008) menyatakan terdapat 5 dimensi yang mempengaruhi responafektif seseorang terhadap pekerjaannya, yaitu 1). Pekerjaan itu sendiri, yaitu sejauh manapekerjaan menyediakan kesempatan seseorang untuk belajar memperoleh tanggung jawab dalamsuatu tugas tertentu dan tantangan untuk pekerjaan yang menarik. 2). Bayaran, yaitu upah yangdiperoleh seseorang sebanding dengan usaha yang dilakukan dan sama dengan upah yang diterimaoleh orang lain dalam posisi kerja yang sama. 3). Kesempatan untuk promosi, yaitu kesempatanseseorang untuk meraih atau dipromosikan ke jenjang yang lebih tinggi dalam organisasi. 4).Atasan, yaitu kemampuan atasan untuk memberikan bantuan tehnis dan dukungan terhadappekerjaan yang menjadi tanggung jawab para bawahan. 5). Rekan kerja, yaitu sejauh mana rekankerja secara tehnis cakap dan secara social mendukung tugas rekan kerja lainnya.

Abdurrahmat(2006) memaparkan bahwa indikator kepuasan kerja hanya diukur dengan kedisiplinan, moral kerja dan turnover kecil. Jadi, apabila kedisiplinan, moral kerja dan turnover karyawan besar, maka kepuasan kerja karyawan di suatu organisasi tersebut berkurang.

\section{Kinerja Pegawai}

Mathis dan Jackson dalam (Susanti \& Palupiningdyah(2016)berpendapat bahwa kinerja pada dasarnya adalah apa yang dilakukan atau tidak dilakukan karyawan. SedangkanMangkunegara(2009)menyatakan kinerja sebagai hasil kerja baik secara kualitas dan kuantitas yang dicapai oleh seorang pegawai dalam melaksanakan tugasnya sesuai dengan tanggung jawab yang diberikan kepadanya.

Bernardin \& Russell(1993) memberikan pengertian kinerja sebagai berikut : "performance is defined as the record of outcomes produced on a specified job function or activityduring time period". Prestasi atau kinerja adalah catatan tentang hasil-hasil yang diperoleh darifungsi-fungsi pekerjaan tertentu atau kegiatan selama kurun waktu tertentu.

Untuk mengukur kinerja karyawan, dapat digunakan beberapa dimensi mengenai kriteriakinerja yang menurut
Bernardin \& Russell(1993:135) adalah sebagai berikut: 1). Kualitas(Quality), yaitu merupakan tingkatan dimana proses atau hasil dari penyelesaian suatu kegiatanmendekati sempurna. 2). Kuantitas (Quantity), yaitu merupakan produksi yang dihasilkan dapatditunjukkan dalam satuan mata uang, jumlah unit, atau jumlah siklus kegiatan yang diselesaikan. 3)Ketepatan waktu (timelinnes), yaitu merupakan dimana kegiatan tersebut dapat diselesaikan, atausuatu hasil produksi dapat dicapai, pada permulaan waktu yang ditetapkan bersamaan koordinasidengan hasil produk yang lain dan memaksimalkan waktu yang tersedia untuk kegiatankegiatanlain. 4). Efektivitas biaya (cost effectivennes), yaitu merupakan tingkatan dimana sumber dayaorganisasi, seperti manusia, keuangan, teknologi, bahan baku dapat dimaksimalkan dalam arti untukmemperoleh keuntungan yang paling tinggi atau mengurangi kerugian yang timbul dari setiap unit.5). Kebutuhan akan pengawasan (need for supervision), yaitu merupakan tingkatan dimana seorangkaryawan mampu melaksanakan suatu fungsi pekerjaan tanpa membutuhkan bantuan pengawasanatau memerlukan campur tangan pengawas untuk mencegah agar hasil produksi tidak mengalamikerugian. 6). Hubungan antar perseorangan (Interpersonal impact), yaitu merupakan tingkatandimana seorang karyawan mampu untuk mengembangkan perasaan saling menghargai, niat baik, dan kerjasama antara karyawan yang satu dengan yang lain, dan juga pada bawahan

Untuk mengetahui tingkat keberhasilan yang dicapai pegawai maka perlu adanya pengukuran kinerja seperti yang dikemukakan oleh Darma(2004:24) bahwa semua pengukuran kinerja mempertimbangkan hal-hal sebagai berikut :

a. Kuantitas, berkaitan dengan jumlah yang harus diselesaikan atau dicapai.

b. Kualitas, berkaitan dengan mutu yang dihasilkan baik berupa kerapian kerja dan ketelitian kerja atau tingkat kesalahan yang dilakukan pegawai.

c. Ketepatan waktu, yaitu sesuai apa tidak dengan waktu yang direncanakan.

\section{Kerangka Konseptual}

Penelitian ini terdiri dari variabel independent atau variabel bebas (X) yaitu komitmen organisasional, variabel dependent atau variabel terikat (Y) yaitu kinerja pegawai, danvariabel intervening $(\mathrm{Z})$ yaitu kepuasan kerja. Untuk lebih jelasnya maka dapat dilihat dalam bentuksebagai berikut:

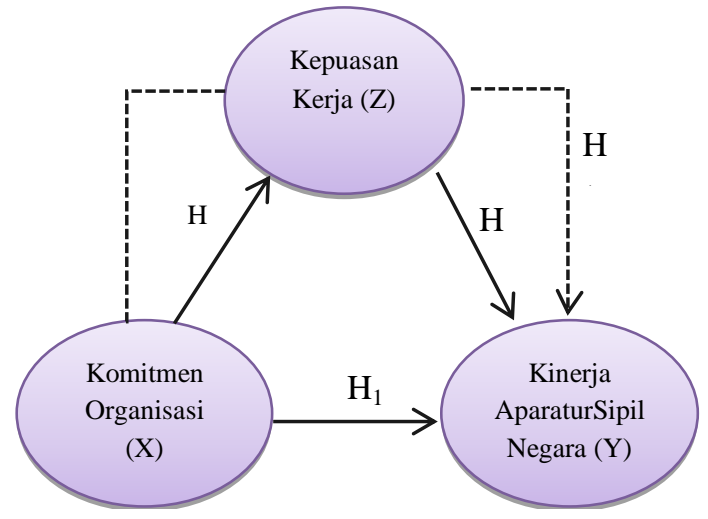

Gambar 1. Kerangka Konseptual 


\section{METODE PENELITIAN}

\section{Pendekatan Penelitian}

Penelitian ini menggunakan metode kuantitatif dengan meneliti data primer yang diperolehdari organisasi. Pengumpulan data dilakukan dengancara menyebar kuesioner yang dibagikan kepada karyawan menggunakan teknik survey. Respondendiminta menjawab pertanyaan yang ada dalam kuesioner dengan menggunkan skala likert.

Penelitianinidilakukanuntuk melihat hubungan antara variabel yang akan diteliti yaitu variable independent berupa komitmen organisasi (X), dengan variable dependen (Y) kinerja aparatur sipil Negara serta menggunakan variabel intervening berupa kepuasan kerja (Z).

\section{Lokasi Penelitian}

Penelitianinidilakukandi Kantor Sekretariat Daerah Kabupaten Jayapurayang merupakan Organisasi Pemerintah Daerah Kabupaten Jayapura. Dan beralamat di Jalan Doyo Sentani, Kompleks Perkantoran Gunung Merah Kemiri,SentaniJayapura.

\section{Populasi dan Sampel \\ Populasi}

Dalam penelitian ini yang menjadi populasi seluruh Aparatur Sipil Negara kantor Sekretariat Daerah Kabupaten Jayapura yang berjumlah 166 Aparatur Sipil Negara.

\section{Sampel}

Menurut Sugiyono(2014:115) sampel adalah bagian atau jumlah dan karakteristik yang dimiliki oleh populasi tersebut. Metode penarikan sampel dalam penelitian ini adalah dengan menggunakan teknik sampling jenuh (Metode Sensus) yang merupakan teknik menentukan sampel dimana semua anggota populasi digunakan sebagai sampel (Sugiyono, 2014).

\section{Definisi Operasional \\ Komitmen Organisasional}

Komitmen organisasional adalah kekuatan individu yang didefinisikan dengan dan dikaitkan bagian organisasi. Hal ini akan merefleksikan sikap individu yang akan tetap sebagai anggota organisasi ditunjukkan dengan kerja kerasnya. Lincoln dan Bashaw dalam Sopiah(2008) komitmen organisasi memiliki tiga indikator yaitu :

a. Kemauan pegawai, dimana adanya keinginan pegawai untuk mengusahakan agar tercapainya kepentingan organisasi.

b. Kesetiaan pegawai, yang mana pegawai berkeinginan untuk mempertahankan keanggotaannya untuk terus menjadi salah satu bagian dari organisasi.

c. Kebanggaan pegawai, ditandai dengan pegawai merasa bangga telah menjadi bagian dari organisasi yang diikutinya dan merasa bahwa organisasi tersebut telah menjadi bagian dalam hidupnya.

Kepuasan Kerja

$$
\text { Kepuasan kerja adalah kondisi psikis yang }
$$

menyenangkan yang dirasakan oleh pekerja/ pegawai di dalam suatu lingkungan pekerjaan atas peranannya dalam organisasi dan kebutuhannya terpenuhi dengan baikAbdurrahmat(2006) memaparkan bahwa indikator kepuasan kerja hanya diukur dengan kedisiplinan, moral kerja dan turnover kecil. Jadi, apabila kedisiplinan, moral kerja dan turnover karyawan besar, maka kepuasan kerja karyawan di suatu organisasi tersebut berkurang.

\section{Kinerja}

Kinerja adalah hasil kerja yang dilakukan oleh seseorang dalam suatu organisasi agar tercapai tujuan yang diiginkan suatu organisasi dan meminimalisir kerugian serta mampu menciptakan pegawai yang handal yang mampu melaksanakan tugasnya sesuai tanggungjawab yang diberikan. Untuk mengetahui tingkat keberhasilan yang dicapai pegawai maka perlu adanya pengukuran kinerja seperti yang dikemukakan oleh Darma (2004:24) bahwa semua pengukuran kinerja mempertimbangkan hal-hal sebagai berikut :

a. Kuantitas, berkaitan dengan jumlah yang harus diselesaikan atau dicapai.

b. Kualitas, berkaitan dengan mutu yang dihasilkan baik berupa kerapian kerja dan ketelitian kerja atau tingkat kesalahan yang dilakukan pegawai.

c. Ketepatan waktu, yaitu sesuai apa tidak dengan waktu yang direncanakan

\section{Teknik Pengumpulan Data \\ Observasi}

Observasi yang dilakukan peneliti dengan melakukan observasi langsung pada objek penelitian pada Sekretariat Daerah Kabupaten Jayapura

\section{Wawancara}

Metode wawancara yang dilakukan dalam penelitian ini yaitu wawancara tidak terstruktruk dan hanya beberapa pertanyaan yang menyangkut permasalahan yang ditanyakanObservasi yang dilakukan peneliti dengan melakukan observasi langsung pada objek penelitian pada Sekretariat Daerah Kabupaten Jayapura

\section{Kuesioner}

Kuesioner dalam penelitian ini berisi beberapa pertanyaan yang berkaitan tentang variabel penelitian. Skalayang digunakan dalam penelitian ini adalah skala Interval.

\section{Studi Kepustakaan}

Studi pustaka dilakukan dengan cara mengumpulkan data dari buku serta jurnal-jurnal yang telah terpublikasi baik di Indonesia maupun Internasional.

\section{Teknik Analisa Data}

\section{A. Uji Instrumen Data}

\section{Uji Validitas}

Digunakan untuk mengetahui seberapa cermat suatu instrumen atau item-item dalam mengukur apa yang ingin diukur. Item kuisioner yang tidak valid berarti tidak dapat mengukur apa yang ingin diukur sehingga 
hasil yang didapat tidak dapat dipercaya, sehingga item yang tidak valid harus dibuang atau diperbaiki. Dalam program SPSS alat uji validitas yang digunakan yaitu dengan korelasi pearson yaitu mengkorelasikan antara skor tiap item dengan skor total item(Priyatno, 2012)

2. Uji Reliabilitas

Uji reliabilitas biasanya menggunakan batasan 0,6 . Menurut Sekaran dalam Priyatno(2012:108), reliabilitas kurang dari 0,6 adalah kurang baik, sedangkan 0,7 dapat diterima dan diatas 0,8 adalah baik. Untuk mengetahui validitas dan reliabilitas data, maka diadakan uji pendahuluan terhadap kuesioner kepada para responden, kemudian skor (data) yang diperoleh diuji validitas dan reliabilitasnya

B. Analisis Structural Equation Modeling (SEM)

Untuk menjawab rumusan masalahdanmelakukan pengujian terhadap hipotesis yang diajukan, maka data yang diperoleh selanjutnya akan diolah sesuai dengan kebutuhan analisis. Untuk kepentingan pembahasan, data diolah dan dipaparkanberdasarkan prinsip-prinsip statistic deskriptif,sedangkan untuk kepentingan analisis dan pengujian hipotesis digunakan pendekatan statistik inferensial.

Untuk dapat menjawab pertanyaan penelitian danmenilai model yang disusun, teknik analisis yang akan digunakan adalah Structural Equation Modeling (SEM) dengan menggunakan paket program AMOS (Analysis of Moment Structure) versi 24 dan SPSS (Statistical Program for Social Sciences) versi 22. Penggunaan SEM memungkinkan penelitiuntukmenguji hubungan antara variabel yang kompleks untuk memperoleh gambaran menyeluruh mengenai keseluruhan model SEM secara bersama-sama

\section{HASIL DAN PEMBAHASAN}

A. Deskripsi Variabel Penelitian

1. Deskripsi Variabel Komitmen Organisasi (X) Berdasarkan tabel 4.5 di atas menunjukkan bahwa jawaban dari 166 responden atas variabel Komitmen Organisasi pada Sekretariat Daerah Kabupaten Jayapura secara deskripsi menunjukkan nilai terendah 21,00 , nilai tertinggi 30,00 , nilai rata-rata 25,1084 , dengan standar deviasi sebesar 1,889141

2. Deskripsi Variabel Komitmen Organisasi (X) Berdasarkan tabel 4.5 di atas menunjukkan bahwa jawaban dari 166 responden atas variabel Kepuasan Kerja pada Sekretariat Daerah Kabupaten Jayapura secara deskripsi menunjukkan nilai terendah 21,00, nilai tertinggi 29,00 , nilai rata-rata 25,2048 , dengan standar deviasi sebesar 1,87655

3. Deskripsi Variabel Komitmen Organisasi (X) Berdasarkan tabel 4.5 di atas menunjukkan bahwa jawaban dari 166 responden atas variabel Kinerja Pegawai pada Sekretariat Daerah Kabupaten Jayapura secara deskripsi menunjukkan nilai terendah 21,00, nilai tertinggi 28,00, nilai rata-rata 25,0422, dengan standar deviasi sebesar1,95201

Tabel 4.5Descriptive Statistics

\begin{tabular}{|l|c|r|r|r|r} 
& N & Minimum & Maximum & Mean & Std. Deviation \\
\hline Komitmen Organisasi & 166 & 21,00 & 30,00 & 25,1084 & 1,88141 \\
\hline Kepuasan Kerja & 166 & 21,00 & 29,00 & 25,2048 & 1,87655 \\
\hline Kinerja Pegawai & 166 & 21,00 & 28,00 & 25,0422 & 1,95201 \\
\hline Valid N (listwise) & 166 & & & & \\
\hline Sumber : Hasil Output SPSS 25 & & &
\end{tabular}

Sumber : Hasil Output SPSS 25

\section{B. Hasil Uji Instrumen Penelitian}

1. Hasil Uji Validitas

Pada tabel 4.6 menunjukkan bahwa semua item yang digunakan untuk mengukur variabel penelitian dalam penelitian ini mempunyai koefisien korelasi $>\mathrm{r}$ tabel. Dengan demikian semua item yang digunakan sebagai pengukur dari variabel rekrutmen tersebut adalah valid.

\begin{tabular}{|c|c|c|c|c|c|}
\multicolumn{1}{c|}{ Tabel 4.6Hasil Uji Validitas } \\
\hline \multirow{2}{*}{ Variabel } & Item Pernyataan & Koefisien Korelasi & $\mathbf{r}_{\text {tabel }}$ & $\begin{array}{c}\text { Sig } \\
\text { (2-Tailed) }\end{array}$ & Keterangan \\
\hline \multirow{2}{*}{$\begin{array}{c}\text { Komitmen } \\
\begin{array}{c}\text { Organisasi } \\
(\mathrm{X})\end{array}\end{array}$} & $\mathrm{X} .1$ & 0,834 & 0,152 & 0,000 & Valid \\
\cline { 2 - 6 } & $\mathrm{X} .2$ & 0,807 & 0,152 & 0,000 & Valid \\
\hline \multirow{3}{*}{$\begin{array}{c}\text { Kepuasan Kerja } \\
(\mathrm{Z})\end{array}$} & $\mathrm{X} .3$ & 0,802 & 0,152 & 0,000 & Valid \\
\cline { 2 - 6 } & $\mathrm{Z} .1$ & 0,778 & 0,152 & 0,000 & Valid \\
\cline { 2 - 6 } & $\mathrm{Z} .2$ & 0,792 & 0,152 & 0,000 & Valid \\
\hline
\end{tabular}




\begin{tabular}{|c|c|c|c|c|c|}
\hline \multirow{2}{*}{ Variabel } & Item Pernyataan & Koefisien Korelasi & $\mathbf{r}_{\text {tabel }}$ & $\begin{array}{c}\text { Sig } \\
\text { (2-Tailed) }\end{array}$ & Keterangan \\
\hline \hline \multirow{2}{*}{$\begin{array}{c}\text { Kinerja Pegawai } \\
\text { (Y) }\end{array}$} & Y.1 & Y.2 & 0,843 & 0,152 & 0,000 \\
\cline { 2 - 6 } & Y.3 & 0,776 & 0,152 & 0,000 & Valid \\
\cline { 2 - 6 } & & 0,152 & 0,000 & Valid \\
\hline
\end{tabular}

Sumber: Data diolah (2021)

\section{Hasil Reliabilitas}

Berdasarkan hasil uji reabilitas pada tabel 4.7 menunjukkan bahwa semua variabel penelitian memiliki nilai cronbach alpha diatas 0,70 dengan demikian seluruh variabel penelitian berada pada kategori reliabel dan dapat dilanjutkan untuk dilakukan analisis

Tabel 4.7Hasil Uji Reliabilitas

\begin{tabular}{|l|c|c|c|}
\hline \multicolumn{1}{|c|}{ Variabel } & $\begin{array}{c}\text { Cronbach } \\
\text { Alpha }\end{array}$ & $\begin{array}{c}\text { Standar } \\
\text { Reliabilitas }\end{array}$ & Keterangan \\
\hline Komitmen Organisasi (X) & 0,832 & $>0,70$ & Reliabel \\
\hline Kepuasan Kerja (Z) & 0,822 & $>0,70$ & Reliabel \\
\hline Kinerja Pegawai (Y) & 0,823 & $>0,70$ & Reliabel \\
\hline
\end{tabular}

Sumber: Data diolah (2021)

\section{Estimasi dan Pengujian Model Struktural}

1. Evaluasi Normalitas

Normalitas univariate dan multivariate terhadap data yang digunakan dalam analisis ini diuji dengan menggunkan Amos 24. Persyaratanasumsi normalitas secara multivariate yang tidak bisa dipenuhi dalam pengujian model persamaan struktural pada penelitian yang sesungguhnya dan teknik estimasi statistik yang ada saat ini tidak memadai untuk menguji model persamaan struktural untuk data yang tidak berdistribusi normal. Disamping itu data yang digunakan adalah data primer yang sulit untuk memperoleh sebaran data yang mengikuti distribusi normal, sehingga menurutKline(2011)bahwa jika data telah berdistribusi normal secara univariate dapat dianggap telah mencukupi untuk pengujian model persamaan struktural, meskipun data tidak berdistribusi normal secara multivariate

Tabel 4.8Hasil Uji Normalitas

\begin{tabular}{|c|rrrrrr|}
\hline Variable & $\min$ & $\max$ & skew & \multicolumn{1}{c|}{ c.r. } & kurtosis & \multicolumn{1}{c|}{ c.r. } \\
\hline Y.3 & 7,000 & 10,000 &,- 013 &,- 067 &,- 843 & $-2,218$ \\
Y.2 & 7,000 & 10,000 &,- 486 & $-2,557$ &,- 410 & $-1,078$ \\
Y.1 & 7,000 & 10,000 &,- 368 & $-1,933$ & $-1,024$ & $-2,694$ \\
Z.3 & 7,000 & 10,000 &, 091 &, 478 &,- 762 & $-2,005$ \\
Z.2 & 7,000 & 10,000 &,- 359 & $-1,891$ &,- 278 &,- 732 \\
Z.1 & 7,000 & 10,000 &,- 072 &,- 379 &,- 398 & $-1,048$ \\
X.3 & 7,000 & 10,000 &, 090 &, 471 &,- 494 & $-1,299$ \\
X.2 & 7,000 & 10,000 &, 027 &, 143 &,- 507 & $-1,333$ \\
X.1 & 7,000 & 10,000 &,- 352 & $-1,853$ &,- 442 & $-1,162$ \\
Multivariate & & & & & 9,689 & 4,436 \\
\hline
\end{tabular}

Sumber: Hasil Output AMOS 24 (2021)

\section{Evaluasi Outliers}

Berdasarkan tabel 4.9 terlihat nilai tertinggi terletak pada observasi ke 110sebesar 26.007 yang masih dibawah 27,88. Berdasarkan uraian tersebut dapat disimpulkan tidak terdapat adanya multivariate outliers dari data yang digunakan dalam penelitian ini, sehingga seluruh observasi yang berjumlah 166 responden tidak ada yang dikeluarkan dan bisa digunakan untuk keperluan analisis. 
Tabel 4.9HasilMultivariate outliers

\begin{tabular}{|r|rrr|}
\hline Observation number & Mahalanobis d-squared & $\mathrm{p} 1$ & $\mathrm{p} 2$ \\
\hline 110 & 26,007 &, 002 &, 287 \\
146 & 26,007 &, 002 &, 046 \\
128 & 24,314 &, 004 &, 027 \\
150 & 23,022 &, 006 &, 020 \\
145 & 22,312 &, 008 &, 011 \\
118 & 20,981 &, 013 &, 020 \\
12 & 18,954 &, 026 &, 135 \\
114 & 18,810 &, 027 &, 080 \\
141 & 18,519 &, 030 &, 060 \\
$\ldots$ & $\ldots$ & $\ldots$ & $\ldots$ \\
\hline
\end{tabular}

Sumber: Hasil Output AMOS 24 (2021)

3. Evaluasi Kriteria Goodness-of-fit

Untuk mengujinya digunakan Structural Equation Modeling (SEM) dengan bantuan program AMOS 24.

a. Chi Square

Nilai Chi-Square dalam penelitian ini adalah 31,787 dan probalitas 0,132 sehingga uji ketepatan model dengan berdasarkan nilai chi-square di katagorikan termasuk memiliki kesesuaian yang fit

b. Chi-square/Degree of Freedom(CMIN/DF) Nilai CMIN/DF yang disyaratkan untuk menentukan ketepatan model <2. Nilai CMIN/DF dalam penelitian ini 1,324lebih kecil dari nilai 2 sehingga dapat dikatakan nilai CMIN/DF merupakan nilai yang fit

c. Root Mean Square Error of Approximation(RMSEA)

Nilai RMSEA kurang dari 0,05 atau 0,08 merupakan ukuran yang dapat diterima. Nilai RMSEA dalam penelitian ini adalah 0,044 kurang dari nilai 0,08 sehingga oleh karena itu uji ketepatan model dengan berdasarkan nilai RMSEA dikatagorikan termasuk fit.

d. Goodness of Fit Index (GFI)

Nilai Goodness of Fit Index (GFI) dalam penelitian ini adalah 0,959, sehingga model di kategorikan termasuk fit.

e. Comparative Fit Index (CFI)

Nilai penerimaan yang direkomendasikan adalah CFI > 0,95. Dalam penelitian ini diperoleh nilai CFI sebesar 0,982 sehingga uji ketepatan model berdasarkan nilai CFI dikategorikan termasuk fit.

f. Tucker Lewis Index

Nilai Tucker Lewis Index (TLI) yang dihasilkan dalam penelitian ini adalah 0,973sehingga dikatagorikan termasuk fit.

g. Adjusted Goodness of Fit Index

Nilai Adjusted Goodness of Fit dalam penelitian ini adalah 0,923 lebih besar dari 0,90 sehingga uji ketepatan model berdasarkan nilai AGFI dikatagorikan termasuk fit.

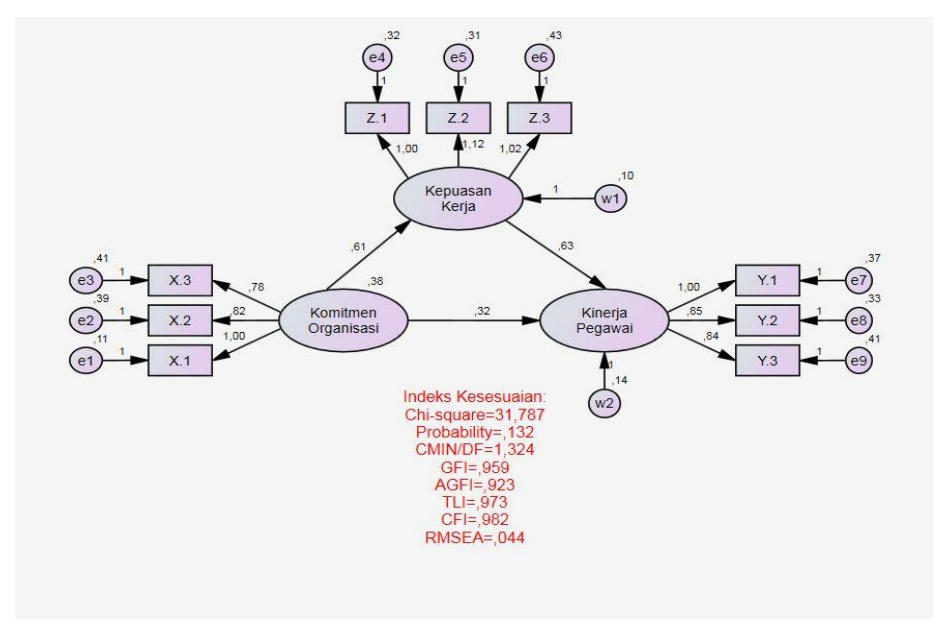

Gambar 4.1Analisis Model Persamaan Struktural 
Berdasarkan penilaian ketepatan model seperti yang dijelaskan di atas, maka lebih

jelasnya dapat dilihat pada Tabel 4.10berikut ini:

Tabel 4.10Hasil Goodness-of-Fit Model

\begin{tabular}{|c|c|c|c|}
\hline $\begin{array}{c}\text { Goodness- } \\
\text { of-fit } \\
\text { Indices }\end{array}$ & Cut-off Value & Hasil & $\begin{array}{c}\text { Evaluasi } \\
\text { Model }\end{array}$ \\
\hline Chi-Square & $\begin{array}{c}\text { Diharapkan } \\
\text { Kecil }\end{array}$ & 31,787 & Fit \\
\hline Probability & $\geq 0,05$ & 0,132 & Fit \\
\hline CMIN/DF & $\leq 2,0$ & 1,324 & Fit \\
\hline RMSEA & $\leq 0,08$ & 0,044 & Fit \\
\hline CFI & $\geq 0,95$ & 0,982 & Fit \\
\hline TLI & $\geq 0,95$ & 0,973 & Fit \\
\hline GFI & $\geq 0,90$ & 0,959 & Fit \\
\hline AGFI & $\geq 0,90$ & 0,923 & Fit \\
\hline
\end{tabular}

Sumber: Data diolah (2021)

\section{Uji Hipotesis}

Pengujian dilakukan terhadap 4 hipotesis yang diajukan. Pengujian hipotesis dilakukan dengan menggunakan nilai t-value dengan tingkat signifikansi 0,05. Nilai t-value dalam program AMOS merupakan nilai Critical Ratio (c.r) pada
Regression Weight dari fitmodel. Apabila nilai Critical Ratio (c.r) $\geq 1,967$. Atau nilai probabilitas $(\mathrm{P}) \leq 0,05$ maka hipotesis penelitian diterima. Hasil analisis ini dilihat pada Tabel berikut ini :

Tabel 4.11Uji Hipotesis

\begin{tabular}{|c|c|c|c|c|c|c|c|}
\hline \multicolumn{3}{|c|}{ Variabel } & Estimate & S.E. & C.R. & $\mathrm{P}$ & Label \\
\hline $\begin{array}{l}\text { Kepuasan_Kerj } \\
\text { a }\end{array}$ & $<-$ & $\begin{array}{l}\text { Komitmen_Organis } \\
\text { asi }\end{array}$ & ,613 & ,097 & 6,332 & $* * *$ & \\
\hline $\begin{array}{l}\text { Kinerja_Pegaw } \\
\text { ai }\end{array}$ & $<--$ & Kepuasan_Kerja & ,631 & ,236 & 2,671 & ,008 & \\
\hline $\begin{array}{l}\text { Kinerja_Pegaw } \\
\text { ai }\end{array}$ & $<---$ & $\begin{array}{l}\text { Komitmen_Organis } \\
\text { asi }\end{array}$ &, 321 &, 174 & 1,845 &, 065 & \\
\hline
\end{tabular}

Sumber: Hasil Output AMOS 24 (2021)

\section{a. Pengujian Hipotesis 1}

Berdasarkan hasil pengujian statistik dari hipotesis pertama yang terlihat pada Tabel 4.11 menunjukkan bahwa nilai parameter estimasi sebesar 0,321, nilai standar eror sebesar 0,174 dan nilai critical ratio sebesar 1,845 dengan nilai probabilitas 0,065 . Dengan menggunakan tingkat alfa $(\alpha)=0,05$ maka dapat disimpulkan bahwa hipotesis pertama yang menyatakan bahwa Komitmen Organisasi Berpengaruh terhadap Kinerja Pegawai ditolak, yang artinya dalam penelitian ini komitmen organisasi tidak berpengaruh terhadap kinerja pegawai b. Pengujian Hipotesis 2

Berdasarkan hasil pengujian statistik dari hipotesis kedua yang terlihat pada Tabel 4.11 menunjukkan bahwa nilai parameter estimasi sebesar 0,613, nilai standar eror sebesar 0,097 dan nilai critical ratio sebesar 6,332 dengan nilai probabilitas 0,000 . Dengan menggunakan tingkat alfa $(\alpha)=0,05$ maka dapat disimpulkan bahwa hipotesis kedua yang menyatakan bahwa Komitmen Organisasi Berpengaruh terhadap Kepuasan Kerja dapat diterima, yang artinya dalam penelitian ini komitmen organisasi berpengaruh positif dan signifikan terhadap 
kepuasan kerja.

\section{c. Pengujian Hipotesis 3}

Berdasarkan hasil pengujian statistik dari hipotesis ketiga yang terlihat pada Tabel 4.11 menunjukkan bahwa nilai parameter estimasi sebesar 0,631, nilai standar eror sebesar 0,236 dan nilai critical ratio sebesar 2,671 dengan nilai probabilitas 0,008 . Dengan menggunakan tingkat alfa $(\alpha)=0,05$ maka dapat disimpulkan bahwa hipotesis kedua yang menyatakan bahwa Kepuasan Kerja Berpengaruh terhadap Kinerja Pegawai dapat diterima, yang artinya dalam penelitian ini kepuasan kerja berpengaruh positif dan signifikan terhadap kinerja pegawai.

d. Pengujian Hipotesis 4

Dalam hipotesis keempat ini peneliti mengambil kesimpulan dari hubungan yang terjadi antar setiap variabel dan dapat disimpulkan bahwa hubungan komitmen organisasi (X) terhadap kepuasan kerja (Z) berpengaruh positif dan signifikan, Hubungan antara kepuasan kerja (Z) terhadap Kinerjapegawai (Y) juga mempunyai Pengaruh positif dan signifikansi, maka dari itu dalam penelitian ini dapat disimpulkan bahwa komitmen organisasi (X) berpengaruh terhadap Kinerjapegawai (Y) melalui kepuasan kerja (Z). Sehingga Hipotesis keempat dapat diterima

5. Analisis Peran Variabel

Dalam penelitian ini ditemukan bahwa komitmen organisasi yang diposisikan sebagai variabel independen tidak berpengaruh terhadap variabel kinerja pegawai yang diposisikan sebagai variabel dependen. Dengan tidak ada pengaruh tersebut, maka yang dipertanyakan adalah apakah konsep baru kepuasan kerja dapat berperan sebagaimana yang diharapkan untuk menjembatani kesenjangan penelitian yang telah diuraikan sebelumnya. Hal ini dapat dilihat dari seberapa besar tingkat signifikansi dari variabel mediasi. Hasil pengujian peran varibel mediasi terlihat pada hasil sobel test yang dihitung secara online pada http://www.danielsoper.com/ yang terlihat pada gambar berikut ini.

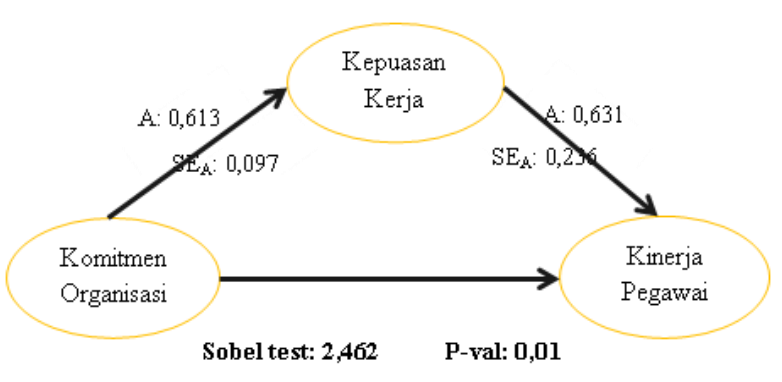

Gambar 4.2. Pengujian Sobel Test

Hasil pengujian Sobel Test sebagaimana terlihat pada Gambar 4.2 menunjukkan bahwa nilai signifikansi dari peran mediasi variabel kepuasan kerja yang terlihat pada P-val sobel test adalah 0,01 , yang berarti bahwa peran variabel kepuasan kerja siginifikasi pada level $\alpha=0,05$. Hal ini mengandung makna bahwa variabel kepuasan kerja secara signifikan berperan sebagai variabel mediasi antara komitmen organisasi dan kinerjapegawai.

Dalam penelitian ini, variabelkepuasan kerja berperan secara signifikan dalammemediasi pengaruh komitmen organisasi terhadap kinerjapegawai. Hal ini terlihat dari nilai Sobel test $(\mathrm{Z})$ sebesar 2,462 dengan nilai signifikansi sebesar 0,01 , sedangkan nilai signifikansi pengaruh langsung komitmen organisasi terhadap kinerjasebesar 0,065

\section{Pembahasan}

\section{Pengaruh Komitmen Organisasi Terhadap Kinerja Pegawai \\ Berdasarkan teori, komitmen} organisasi merupakan komitmen yang dimikiki oleh seorang pegawai terhadap organisasi dimana pegawai tersebut bekerja. Pegawai yang memiliki komitmen organisasi yang tinggi akan berusaha melibatkan diri untuk dapat memajukan perusahaan. Namun setelah dilakukan penelitian diketahui bahwa komitmen organisasi tidak berpengaruh terhadap kinerja pegawai yang ada di Sekretariat Daerah Kabupaten Jayapura. Hal ini dapat dikarenakan terdapat faktor-faktor lain yang lebih dominan dalam mempengaruhi kinerja pegawai.

Hasil penelitian ini sejalan dengan penelitian yang dilakukan oleh Novita et al.(2016)yang menunjukkan bahwa komitmen organisasi tidak berpengaruh terhadap peningkatan kinerja.

2. Pengaruh Komitmen Organisasi Terhadap Kepuasan Kerja

Komitmen organisasi merupakan tingkat sampai sejauh mana seorang pegawai 
memihak pada suatu organisasi tertentu dan tujuan-tujuannya, serta berniat untuk mempertahankan keanggotaannya dalam organisasi tersebut. Seringkali, komitmen organisasional diartikan secara individu dan berhubungan dengan keterlibatan orang tersebut pada organisasi tersebut. Seseorang dengan komitmen organisasi yang tinggi akan lebih mencintai organisasinya dan enggan meninggalkan organisasi, sehingga akan merasakan kepuasan kerja.Hasil penelitian ini sejalan dengan penelitian yang dilakukan oleh Hartono et al.(2013)yang menunjukkan bahwa komitmen organisasi berpengaruh positif dan signifikan terhadap kepuasan kerja.

3. Pengaruh Kepuasan Kerja Terhadap Kinerja Pegawai

Berdasarkan teori yang ada, kepuasan kerja merupakan perasaan atau keadaan emosi pegawai yang baik terhadap pekerjaannya. Perasaan atau keadaan emosi tersebut diwujudkan dalam sikap terhadap pekerjaan dan segala sesuatu di lingkungannya. Pegawai dengan tingkat kepuasan yang tinggi akan menunjukkan sikap positif terhadap pekerjaannya. Hal ini selaras dengan hasil dari penelitian ini yang menunjukkan bahwa kepuasan kerja memiliki pengaruh yang positif dan signifikan terhadap kinerja karyawan. Hasil penelitian ini sejalan dengan penelitian yang dilakukan oleh Fadhil \& Mayowan(2018)yang menunjukkan bahwa kepuasan kerja berpengaruh positif dan signifikan terhadap peningkatan kinerja

4. Pengaruh Komitmen Organisasi Terhadap Kinerja Pegawai Melalui Kepuasan Kerja Hasil penelitian ini menunjukkan bahwa nilai signifikansi dari peran mediasi variabel kepuasan kerja yang terlihat pada P-val sobel test adalah 0,01 , yang berarti bahwa peran variabel kepuasan kerja siginifikasi pada level $\alpha=0,05$. Hal ini mengandung makna bahwa variabel kepuasan kerja secara signifikan berperan sebagai variabel mediasi antara komitmen organisasi dan kinerja pegawai.Berdasarkan teori yang ada, kinerja pegawai merupakan hasil kerja yang diukur dalam periode tertentu oleh kantor. Kinerja ditampilkan oleh pegawai sesuai peranannya dalam organisasi. Kinerja pegawai dipengaruhi oleh faktor individu yang meliputi komitmen organisasi dan faktor psikologis yang meliputi kepuasan kerja. Karyawan yang memiliki kepuasan kerja dan komitmen organisasi yang tinggi menunjukkan kinerja yang baik.

\section{PENUTUP}

\section{A. Simpulan}

Berdasarkan hasil penelitian dan pembahasan yang telah dikemukakan sebelumnya, maka kesimpulan penelitian ini adalah sebagai berikut :

1. Komitmen organisasi tidak berpengaruh terhadap kinerja pegawai pada Sekretariat Daerah Kabupaten Jayapura.

2. Komitmen organisasi berpengaruh positif dan signifikan terhadap kepuasan kerja pada Sekretariat Daerah Kabupaten Jayapura.

3. Kepuasan kerja berpengaruh positif dan signifikan terhadap kinerja pegawai pada Sekretariat Daerah Kabupaten Jayapura.

4. Kepuasan kerja dapat memediasi pengaruh komitmen organisasi terhadap kinerja pegawai pada Sekretariat Daerah Kabupaten Jayapura

B. Saran

Berdasarkankesimpulandarihasilpenelitian,ma

kasaranyangdapat melaluihasilkajianiniadalah sebagaiberikut:

1. Perlunya peningkatan kesejahteraan kepada pegawai dengan kinerja yang baik. Hal ini dapat meningkatkan kepuasan kerja yang berakibat pada tingginya komitmen organisasi.

2. Variabel dan model yang digunakan dalam penelitian ini masih sangat terbatas, oleh karena itu untuk penelitian selanjutnya dapat ditambahkan variabel lain di luar variabel yang telah diteliti. Selainitu, bisa dilakukan penelitian dengan obyek berbeda yaitu perusahaan swasta karena perusahaan swastalebih variatif dalam hal sumber daya manusia daripada instansi pemerintah

\section{DAFTAR PUSTAKA}

Abdurrahmat, F. (2006). Manajemen Sumber Daya Manusia. Jakarta: Rineka Cipta.

Akbar, F., Hamid, D., \& Djudi, M. (2016). Pengaruh Kepuasan Kerja Terhadap Komitmen Organisasional Dan Kinerja Karyawan (Studi pada Karyawan Tetap PG Kebon Agung Malang). Jurnal Administrasi Bisnis S1 Universitas Brawijaya, 38(2), 79-88.

Bernardin, H. J., \& Russell, J. E. A. (1993). Human Resource Management: An Experiential Approach. New York: McGraw-Hill.

Darma, A. (2004). Manajemen Supervisi. Jakarta: Rajawali Press.

Fadhil, A., \& Mayowan, Y. (2018). Pengaruh Motivasi Kerja dan Kepuasan Kerja terhadap Kinerja Karyawan AJB Bumiputera. Jurnal Administrasi Bisnis, 54(1), 40-47. Retrieved from http://administrasibisnis.studentjournal.ub.ac.id/index .php/jab/article/view/2215

Hartono, B., \& Setiawan, R. (2013). Pengaruh Komitmen Organisasional Terhadap Kepuasan Kerja Karyawan Paparon's Pizza City Of Tomorrow. Jurnal Agora, l(1), 1-8.

Hasibuan, M. S. P. (2003). Manajemen Sumber Daya 
Manusia. Jakarta: Bumi Aksara.

Kline, R. B. (2011). Principles And Practice Of Structural Equation Modeling (fourth). New York: The Guilford Press.

Kristine, E. (2017). Pengaruh Kepuasan Kerja Dan Komitmen Organisasi Terhadap Kinerja Melalui Motivasi Kerja Pegawai Alih Daya (Outsourcing) Di Pt. Mitra Karya Jaya Sentosa. Jurnal EKSEKUTIF, 14(2), 384-401.

Mangkunegara, A. A. A. P. (2009). Manajemen Sumber Daya Manusia. Bandung: PT. Remaja Rosdakarya.

Mathieu, J. E., \& Zajac, D. M. (1990). A review and metaanalysis of the antecedents, correlates, and consequences of organizational commitment. Psychological Bulletin, 108(2), 171-194. https://doi.org/10.1037/0033-2909.108.2.171

Mekta, H. Q., \& Siswanto, S. (2017). Pengaruh Kepuasan Kerja Dan Komitmen Organisasi Terhadap Kinerja Karyawan PT . Indra Kelana Yogyakarta. Jurnal Profita, 2(1), 1-8.

Novita, N., Sunuharjo, B., \& Ruhana, I. (2016). Pengaruh Kepuasan Kerja Dan Komitmen Organisasional Terhadap Kinerja Karyawan (Studi pada PT. Telekomunikasi Indonesia, Tbk Witel Jatim Selatan, Malang). Jurnal Administrasi Bisnis S1 Universitas Brawijaya, 34(1), 38-46.

Priyatno, D. (2012). Cara Kilat Belajar Analisis Data dengan SPSS 20. Yogyakarta: Andi Offset.

Robbins, S. P., \& Judge, T. A. (2008). Perilaku Organisasi (12th ed.; D. Sunardi, ed.). Jakarta: Salemba Empat.

Sopiah. (2008). Budaya organisasi, komitmen organisasional pimpinan dan pengaruhnya terhadap kepuasan kerja dan kinerja karyawan bank. Jurnal Keuangan Dan Perbankan, 12(2), 308-317.

Sugiyono, S. (2014). Metodologi Penelitian Kuantitatif, Kualitatif $R \& D$. Bandung: CV. Alfabeta.

Suryahadi, Y. W. (2015). Pengaruh Komitmen Dan Kepuasan Kerja Terhadap Kinerja Karyawan Pada Lukas Tours Dan Travel. Agora, 3(2), 625-630.

Susanti, S., \& Palupiningdyah, P. (2016). Pengaruh Kepuasan Kerja Dan Komitmen Organisasi Terhadap Kinerja Karyawan Dengan TurnOver Intention Sebagai Variabel Intervening. Management Analysis Journal, 5(1), 77-86. 